\title{
TO DISTORT OR NOT TO DISTORT: COMPARATIVE ANALYSIS OF BRITISH AND BULGARIAN MEDIA DISCOURSE REPRESENTATIONS OF FIRE DISASTERS
}

\author{
Ivaylo Gorchev
}

Department of English Studies, Konstantin Preslavsky University of Shumen, Shumen, Bulgaria

\begin{abstract}
Using a comparative approach and utilising a slightly refined version of a framework for discourse representation analysis used by Norman Fairclough, the article aims to study the discourse representations of the public inquiry of the Grenfell Tower Fire and a press conference of the railway carrier Bulmarket concerning the Hitrino train derailment and subsequent fiery explosion by the British and the Bulgarian media respectively, with the intent of identifying the extent of deviation from the original sources in the reporting texts and the use of devices for controlling the reader's perception of the reported discourses. The research shows that the Bulgarian newspapers have adopted to a higher degree the position of interpreters between their readers and the reported sources, since they are less committed to represent the exact form of secondary discourse, even when demarcated as a verbatim quotation and tend to shape its perception by contextualising it within stylistic devices, which allow them to predispose its interpretation by their readers. However, even the British media commitment is not absolute in this respect, as instances of distortions of the secondary discourse and transmissions of the authority of the quoted sources in their texts are also observed, even though to a lesser extent.
\end{abstract}

Key words: discourse representation, primary discourse, secondary discourse, objectivity, $C D A$

\begin{abstract}
About the author: Ivaylo Gorchev is a PhD candidate at the Department of English Studies at Konstantin Preslavsky University of Shumen. He obtained his Bachelor's degree, major "English Philology" in 2001 and in 2018, he received his MA degree, major "English Philology - English Studies and Mass Communications" from the same university. The topic of his PhD thesis is "Analysis of the Bulgarian and the British media discourse on catastrophic events (a Comparative Study)". He is currently a teacher of English at Nikola Yonkov Vaptsarov Foreign Language School, Shumen. His interests include media discourse research on media objectivity and conceptual metaphors. He is also interested in foreign language teaching and music production.
\end{abstract}

e-mail:ivlg@abv.bg

ORCID iD: https://orcid.org/0000-0001-5023-9552

Copyright $(\odot) 2021$ Ivaylo Gorchev

Article history: Received: 18 October 2020; Reviewed: 1 March 2021; Revised: 23 March 2021; Accepted: 25 March 2021; Published: 19 April 2021

This open access article is published and distributed under a Creative Commons Attribution 4.0 International License.

Citation (APA): Gorchev, I. (2021). To distort or not to distort: Comparative analysis of British and Bulgarian media discourse representations of fire disasters. Studies in Linguistics, Culture, and FLT, 9(1), 83-111. doi: 10.46687/SILC.2021.v09i01.005. 


\section{Introduction}

The search for truth epitomised by Pontius Pilate's question Quid est veritas? is an everlasting effort on the part of the investigative journalism, where journalists in the face of considerable danger for their own lives take on the role of investigators of the hidden agenda of people in power and expose their backstage deals, which may result in the resignation of some political figures, like in the case of Richard Nixon and the investigative reporting of Carl Bernstein and Bob Woodward during the Watergate scandal.

At the other end of the continuum stands the gutter press, where truthful reporting is neither present nor expected. Even when the serious press is taken into consideration, the majority of newspaper articles are not investigative in their nature, but rather have an informative function, where the general public is either presented with some new information or publicly expressed opinions. In Framing Muslims in the Bulgarian and the British Media Discourse Desislava Cheshmedzieva-Stoycheva $(2018$, p. 1) states that the tendency of people in general to use their own point of view when presenting information makes researchers "conclude that objective reporting of reality is virtually impossible" and that newspapers tend to conform to "the policy of the organisations that own them" in their ways of presenting news and events so that their focus is "on aspects responding to that policy" (ibid., p. 3). Similar opinion is expressed by van Dijk (2000), as well as by Fowler (1991) and McNair (2008), among others. Thus, journalists tend to opt for particular lexical items or constructions from a set of available options, which allow them to shape their reader's perception of the reported events in accordance with this policy.

The aim of the paper is to conduct a comparative analysis on the discourse representations in two British and two Bulgarian newspapers of the oral and written discourses concerning two catastrophic events, which happened 6 months apart in the Republic of Bulgaria and the United Kingdom and initiated inquiries in their respective countries of origin. The Hitrino train derailment took place on the $10^{\text {th }}$ December 2016 and caused a subsequent explosion and fire in Hitrino, with a death toll of 7 and 29 heavily injured residents of Hitrino as well as 1 heavily injured employee (post switchman), while the Grenfell Tower Fire in London occurred on $14^{\text {th }}$ of June 2017 and caused the death of 72 inhabitants of the tower block. The main intent of the article is the identification of the extent of deviation from the original sources in the reporting texts.

\section{Corpus and Methods of Analysis}

The corpus used for the research consists of four articles excerpted from the electronic databases of Dnevnik (D) and 24 Chasa (24 Ch) for the Bulgarian media discourse and The Guardian $(G)$ and The Sun $(S)$ for the British media discourse. The Bulgarian articles published on $24^{\text {th }}$ January 2020 report a press 
conference given by Svetoslav Parvanov, the deputy manager of the railway carrier Bulmarket, after the announcement on $22^{\text {nd }}$ January 2020 of the prison sentences imposed on the train drivers held responsible for the derailment of freight train No. 90570 in Hitrino. The English articles were published on $4^{\text {th }}$ June 2018 by The Guardian and on $5^{\text {th }}$ June by The Sun report the hearing of Grenfell Tower Inquiry held on $4^{\text {th }}$ June 2018 as well as some documents sent to the inquiry and published on the website of the inquiry on the same day. The whole press conference of Bulmarket was published on the YouTube Channel of RuseMedia and has been retrieved and transcribed, so that the discourse representation in the Bulgarian media can be compared with the original source, something most readers are not in the position to do, while the official transcript and video footage of the hearing of Grenfell Tower Inquiry on $4^{\text {th }}$ June 2018 together with the quoted documents including Dr Barbara Lane's report, Prof Jose Torero's report and Colin Todd's report, published on the website of the inquiry, have been retrieved to the same end.

For the purposes of the analysis, the study utilizes a slightly refined version of a framework for discourse representation used by Norman Fairclough (1995, pp. 54-61), based on the accounts of discourse representation in Leech and Short (1981), McHale (1978), Quirk et al. (1972) and Volosinov (1973), as well as the principles of the systemic functional theory proposed by M. A. K. Halliday (1978) and John R. Searle's Speech Acts (1969).

The term discourse representation is used instead of the more common term speech reporting because not only speech may be represented, but writing as well, and also instead of a transparent reporting of the represented sources, very often an interpretation of these sources is observed. Terminologically, the voice of the reporter is designated by the phrase primary discourse, while the actual words quoted by the reporter - as secondary discourse. Conceptually, first, the possibility that primary and secondary discourse can be, on the one hand, clearly differentiated from each other, and on the other, merged to different degrees is taken into account in the framework. Second, the fact that apart from the message (ideational meaning in Hallidayan terms), some stylistic and expressive meanings of secondary discourse can also be accounted for (the so-called interpersonal meanings in Hallidayan terms). Third, the possibility that the interpretation of secondary discourse may be controlled by its contextualization (stylistic or situational) in primary discourse is also considered. The framework has five parameters: mode, boundary maintenance, stylisticity, situationality and setting (Fairclough, 1995, pp. 54-61).

The differentiation of primary and secondary discourse can be seen from two perspectives. On the one hand, typographically, the primary and secondary discourse should be demarcated by using punctuation and other grammatical conventions. This is reflected in the first parameter of the framework called 
Mode, i.e the way in which secondary discourse is incorporated in primary discourse.

The framework, according to Fairclough (1995, pp. 54-61) incorporates four types of mode: 1. Direct Discourse (DD), where the secondary discourse is clearly differentiated from the primary discourse, using typographical features, e.g. Mrs Thatcher warned Cabinet colleagues: 'I will not stand for any backsliding; 2. Indirect Discourse (ID), where the secondary discourse is introduced through subordination to the reporting clause in the form of a that-clause, with all the necessary changes, like a removal of the quotation marks, a shift from first and second person pronouns to third person pronouns, shift of adverbials, deictics and verbs of movement (for instance come becomes go) and backshift of tenses, e.g. Mrs Thatcher warned Cabinet colleagues that she would not stand for any backsliding $;$; 3. Direct Discourse Slipping $(\mathrm{DD}(\mathrm{S}))$, where just part of the primary discourse is designated typographically as secondary discourse, i.e. the representation of secondary discourse starts as one type (for example ID) and then 'slips' into another one (DD(S)), e.g. Mrs Thatcher warned Cabinet colleagues that she would 'not stand for any backsliding', (such sentences are coded twice - once for the mode they start in and once for the mode they slip in, which is $\operatorname{DD}(\mathrm{S}))$; and 4. Unsignalled (UNSIG), where what is clearly secondary discourse has not been typologically designated as secondary discourse, for example: Mrs Thatcher will not stand for any backsliding used as a headline. UNSIG includes a variant of indirect discourse, where the reporting clause is omitted, and the potentialities of indirect-discourse sentence structure are retained. The latter is defined by Quirk et al. (1972, p. 644) as Free Indirect Speech, e.g: Mrs Thatcher would not stand for any backsliding. A fifth mode, called Indirect Discourse Slipping (ID(S)), not incorporated by Fairclough (1995) is introduced, due to its existence in the Bulgarian media discourse. It is characterized by being distributed between two sentences, with the first sentence representing the secondary discourse as if it is primary discourse (in UNSIGN) and the second sentence introducing the source of the first sentence (in ID(S)), e.g: Преустановяват се всички културни и развлекателни мероприятия на територията на област Варна, като мярка за ограничаването на заразата от коронавирус. Това съобщи на редовен брифинг пред журналисти областният управител Стоян Пасев. (All cultural and entertainment events on the territory of Varna district are suspended as a measure to limit the spread of coronavirus infection. This is what the regional governor Stoyan Pasev announced to journalists at a regular

1. In Bulgarian the reported clause is introduced with the help of the conjunctions $\partial a$ and ye and the tenses are changed into reported verb forms (преизказни глаголни форми), which denote that the speaker has not witnessed the described events but has heard about them from another person. (Pashov, 1989, pp. 371, 150) 
briefing $^{2}$.) The reason for the introduction of this mode is the impossibility of coding the second sentence only within the framework incorporated by Fairclough (1995).

The second angle from which the differentiation of primary and secondary discourse can be viewed is the one connected with the commitment to the faithful representation of the secondary discourse by not changing or allowing it to impose its authority on the primary discourse. The latter is reflected in the second parameter of the framework, namely Boundary maintenance (Fairclough, 1995, p. 58). With respect to deviations from that commitment, there are two possibilities. On the one hand, secondary discourse can be translated into the voice of the reported through vocabulary and other changes, like when the Labour leader Neil Kinnock says, 'Margaret Thatcher must resign' and it appears in an article as 'Maggie must get out'. This is considered a case of incorporation. Alternatively, secondary discourse can invade primary discourse and be presented as such. In this case we observe dissemination. It can be exemplified when the words of Neil Kinnock are presented as the words of the reporter in a newspaper headline, which reads: Margaret Thatcher must resign. Even though dissemination is normally observed in UNSIG, it is also possible to occur in other modes, as well. For example, in the following sentence, which is ID: Margaret Thatcher must resign, says Kinnock, the word order, which deviates from the more straightforward one: Kinnock says that Margaret Thatcher must resign, signifies dissemination, because by placing the secondary discourse in initial position it is put in focus and thus made salient, which results in the preservation of its authority. It should be kept in mind that both incorporation and dissemination can be observed in one and the same sentence despite them seeming to be opposite tendencies, like in Maggie must get out, says Kinnock, where the words of Neil Kinnock are both translated and their authority is kept in the primary discourse by putting the secondary discourse in initial position and thus foregrounding it, while backgrounding the primary discourse by placing it in final position.

As already mentioned, the framework accounts for the possibility that not only the message (ideational meaning in Hallidayan terms) of secondary discourse can be represented but also its stylistic and expressive side (interpersonal meanings in Hallidayan terms). Halliday (1978, pp. 112-113) adopts a ternary ${ }^{3}$ interpretation of language, postulating that it consists of three strata, which are realized in the three metafunctions: the ideational (further subdivided into experiential and logical), the interpersonal and the textual one. From the perspective of the ideational function the speaker (writer) is viewed as an

2. All translations of the original texts in Bulgarian are done by the author.

3. Having three elements, parts, or divisions. 
observer who uses language "about something" to encode his/her own "cultural experience" concerning "the things that are already encoded as facts and as reports" (ibid., p. 112). From the perspective of the interpersonal function the speaker (writer) is viewed as an intruder, who through the expression of his/ her own attitudes and judgements tries to influence both the attitudes and the behavior of others. The relationships concerning the roles of the participants in the particular situation, which include the ones defined by language itself, are expressed through this component. The textual component enables the speaker to actualize the ideational and interpersonal meanings so that language is made relevant to the context of situation. The representation of the interpersonal meaning of secondary discourse is accounted for in the parameter stylisticity.

No interaction takes place in a vacuum but in a specific social environment. According to Halliday $(1978$, p. 33) the context of situation can be described through the notions of field of discourse, tenor of discourse and mode of discourse. The field of discourse refers to the institutional setting where the specific language use takes place, which includes the social activity the speaker and hearer are a part of, as well as the subject matter. It could be a domestic environment for a casual family conversation on wrongdoing, or a court room for a barrister's speech concerning manslaughter. The tenor of discourse concerns the role relationships between the participants in the interaction: a mother and child in the domestic environment and a barrister, a judge, a jury in the legal context. The mode of discourse refers to the chosen channel of communication. It is the spoken medium for both situations, but the chosen register differs significantly between the two of them, colloquial speech for the domestic one and formal language for the legal one. The extent to which the context of situation of secondary discourse is represented is accounted for in the parameter situationality.

It should be noted that both stylisticity and situationality can be used as a vehicle for the contextualization of secondary discourse with a view to controlling its interpretation by the speaker (writer) i.e. they can be used as setting devices. Setting is the last parameter in the framework, relating to "the extent to which and ways in which reader's/listener's interpretation of secondary discourse is controlled by placing it in particular context (or 'cotext')" (Fairclough, 1995, p. 60 ). A number of setting devices can be employed in discourse representation. One of them is the representation of the illocutionary force of the secondary discourse. According to Searle (1969, pp. 23-25), while speaking one performs different types of acts. By uttering words, an utterance act is performed. When an item or an abstraction is referred to and something is predicated about it, a propositional act is performed. Even though different utterances may refer to the same item or abstraction and predicate the same thing about them, simultaneously, some other acts may be performed, such as stating, questioning, commanding, promising etc. In these cases, different illocutionary acts are performed. By 
performing illocutionary acts, the speaker can exert certain effects on the hearer, for instance by arguing, one can persuade somebody, or by warning someone, one can alarm that person. Such acts are recognized as perlocutionary acts. Searle distinguishes between the illocutionary act and the propositional content of that act, noting that some acts may not have a propositional content, like Hurrah or Ouch. In an illocutionary act with a propositional content there are prepositional indicators and illocutionary force indicators. Word order, stress, intonation contour, punctuation, the mood of the verb, and the performative verbs are some of the devices that indicate the illocutionary force of an utterance (Searle, 1969, pp. 29, 30). Searle proposes a classification of illocutionary acts which takes into account Austin's classification of illocutionary acts into his five basic categories of verdictive, expositive, exercitive, behabitive, and commissive but addresses its inadequacies. Searle's classification recognizes five categories of speech acts, which are representative, directive, commissive, expressive and declarations. Illocutionary acts are thought to differ on at least twelve significant dimensions of variation, three of which are used for the description of all five illocutionary acts and are point (or purpose) of the act, direction of fit of the words and the world and expressed psychological states. Representative illocutionary acts have as point of the act the commitment of the speaker to the truth of the expressed proposition, the direction of fit is words fitting the world (express that something is the case) and the expressed psychological state is Belief (that proposition). Directives have as point of act an attempt to get the hearer to do something, the direction of fit is the world fitting the words (the actions of the hearer should follow the words of the speaker), the expressed psychological state is Want (or wish, desire). Commissive illocutionary acts have as point of the act a commitment of the speaker to some future course of action, the direction is again the world fits the words and the expressed psychological state is Intention. Expressive illocutionary acts have as a point the expression of the psychological state specified in the sincerity condition (e.g. I apologize) about a state of affairs specified in the propositional content (for being late), there is no direction of fit, expressed psychological states can vary. With declaratives the point is the alteration of the state of something, the utterance of a declaration brings about a fit which is both words fit the world and the world fits the words and there is no sincerity condition. In order for a declarative illocutionary act to be performed successfully the speaker should have a special position within an institution. It is important to note that Searle's classification is one of illocutionary acts and not of illocutionary verbs. He says that verbs like insist or suggest can be used for the performance of different illocutionary acts. He points out that, for example, I insist that we go to the movies and I insist that the answer is found on p.16 express two different illocutionary acts, directive, and representative, respectively. He also explains that if we substitute insist with suggest in any of the sentences, this will not render a different illocutionary 
act but only the intensity with which the illocutionary point is presented will be changed (see Searle, 1976). Searle does not discuss illocutionary acts with respect to discourse reporting but Caldas-Coulthard (1994) postulates that the choice of a reporting (or quoting) verb used to introduce the secondary discourse can be of a paramount importance for the secondary discourse interpretation. She distinguishes between speech-reporting verbs, descriptive verbs, and transcript verbs. Speech-reporting verbs can be neutral structuring verbs (say, tell, ask, enquire), metapropositional verbs, and metalinguistic verbs (narrate, quote, recount). Metapropositional verbs are further subdivided into assertives (remark, explain, agree, announce etc.), directives (urge, instruct, order) and expressives (accuse, complain, claim). Descriptive verbs, which can be prosodic (cry, intone, shout) or paralinguistic, which can be further subdivided into voice qualifiers, connoting manner (whisper, murmur, mutter) or voice qualification, connoting attitude (laugh, giggle, sigh, gasp, groan). Transcript verbs can signal the relation to other parts of discourse (repeat, echo, add, amend), or the progress of discourse (pause, go on, hesitate, continue). The reporter does not presuppose the interpretation of the secondary discourse, when it is introduced with a neutral structuring verb, and the illocutionary force of the secondary discourse has to be derived from the quoted utterances without any assistance from the reporter of the utterance and this renders unbiased, transparent reporting. On the other hand, the presence of the author in the text can be conveyed by the illocutionary glossing verbs, which make the illocutionary force of the quote explicit (see Caldas-Coulthard, 1994, pp. 305-306). According to Machin and Mayr (2012, pp. 57-58) the same complaint introduced with the verb whinged (which is an expressive) as opposed to the more neutral say can undermine the credibility of the statement and the person who has uttered it by giving the impression that the complaint is more of a natural result of the speaker's character. Conversely, if the statement is introduced with the verb announce (which is an assertive), much more legitimacy will be ascribed to it. While analysing the representation of a statement made by Tony Blair concerning the Iraq war, where he had said that Britain would ultimately be able to look back on the conflict with 'immense pride', which was introduced with the verb insist, Machin and Mayr say that the use of that verb gives an impression of a man who lacks confidence and credibility. They support their position by giving a pair of examples, where a librarian explains that a student must return a book immediately vs insists that a student must return a book immediately. In the first case the librarian explains rules and their authority is clear, while in the second case their authority is challenged (Machin \& Mayr, 2012, pp. 63-64). In conjunction with the reporting verb, style adjuncts can also be used as setting devices to control the interpretation of the secondary discourse. Last but not least, formulation (Heritage \& Watson, 1979), i.e. "a summarizing gist of the secondary discourse 
before it occurs in a fuller representation" is another potential setting device (Fairclough, 1995, p. 61).

\section{Analysis}

The four articles have been analyzed both quantitatively and qualitatively. With respect to the quantitative analysis of the discourse representation, two fundamental questions are of paramount importance: a) what constitutes an instance of secondary discourse representation and b) what determines the boundaries of each instance so that an objective comparison between the articles is drawn. As for the first question an instance of secondary discourse representation is any representation of ideas based on the source materials no matter if these representations are marked as secondary discourse or not, for example: at the hearing, a video footage with the burning tower is shown, where certain more or less shocking utterances are heard and both newspapers report some of them. Since these utterances are not present in the official transcript of the hearing, these have not been considered to be instances of discourse representation and have been excluded from the analysis.

As for the second question, because complete thoughts are typographically demarcated as separate sentences, the boundaries of an instance in most cases are thought to coincide with the boundaries of a sentence. This means that most instances are single sentences. However, there are a few cases, where one complete thought stretches between two adjacent sentences, which could have been combined in a single compound sentence. Such pairs have been coded as a single instance. When, typographically, secondary discourse is demarcated as such with quotation marks, the boundaries are determined by the quotation marks and thus there are cases where up to six sentences are presented between two quotation marks in the Bulgarian media discourse and those have been considered a single instance. Each case of $\mathrm{DD}(\mathrm{S})$ or $\operatorname{ID}(\mathrm{S})$ is counted two times - the mode it starts in and the mode it slips in. For the former, it is usually ID or UNSIG / DD(S), while for the latter, it is USIGN/ ID(S). The analysis will be organized by consecutively examining each parameter from the framework and the interaction between some of the parameters.

\section{Table 1.}

Mode of representation

\begin{tabular}{|c|c|c|c|c|c|c|c|c|c|c|c|c|c|c|}
\hline & \multicolumn{2}{|c|}{ The Guardian } & \multicolumn{2}{|c|}{ The Sun } & \multicolumn{2}{|c|}{$\begin{array}{l}\text { BR } \\
\text { Newspapers }\end{array}$} & \multicolumn{2}{|c|}{ Monitor } & \multicolumn{2}{|c|}{24 Chasa } & \multicolumn{2}{|c|}{\begin{tabular}{|l} 
BG \\
Newspapers
\end{tabular}} & \multicolumn{2}{|c|}{$\begin{array}{l}\text { BR and BG } \\
\text { Newspapers }\end{array}$} \\
\hline & No. & $\%$ & No. & $\%$ & No. & $\%$ & No. & $\%$ & No. & $\%$ & No. & $\%$ & No. & $\%$ \\
\hline ID & $18 / 37$ & 49 & $7 / 30$ & 23 & $25 / 67$ & 37 & $3 / 10$ & 30 & $8 / 24$ & 33 & $11 / 34$ & 32 & $\underline{36 / 101}$ & $\underline{36}$ \\
\hline $\mathrm{ID}(\mathrm{S})$ & $0 / 37$ & 0 & $0 / 30$ & 0 & $0 / 67$ & 0 & $1 / 10$ & 10 & $1 / 24$ & 4 & $2 / 34$ & 6 & $\underline{2 / 101}$ & $\underline{2}$ \\
\hline
\end{tabular}




\begin{tabular}{|l|l|l|l|l|l|l|l|l|l|l|l|l|l|l|}
\hline $\mathrm{DD}$ & $4 / 37$ & 11 & $11 / 30$ & 37 & $\mathbf{1 5 / 6 7}$ & $\mathbf{2 2}$ & $4 / 10$ & 40 & $2 / 24$ & 8 & $\mathbf{6} / \mathbf{3 4}$ & $\mathbf{1 8}$ & $\underline{\mathbf{2 1} / \mathbf{1 0 1}}$ & $\underline{\mathbf{2 1}}$ \\
\hline $\mathrm{DD}(\mathrm{S})$ & $11 / 37$ & 30 & $4 / 30$ & 13 & $\mathbf{1 5 / 6 7}$ & $\mathbf{2 2}$ & $0 / 10$ & 0 & $0 / 24$ & 0 & $\mathbf{0 / 3 4}$ & $\mathbf{0}$ & $\underline{\mathbf{1 5} / \mathbf{1 0 1}}$ & $\underline{\mathbf{1 5}}$ \\
\hline UNSIG & $4 / 37$ & 11 & $8 / 30$ & 27 & $\mathbf{1 2 / 6 7}$ & $\mathbf{1 8}$ & $2 / 10$ & 20 & $13 / 24$ & 54 & $\mathbf{1 5 / 3 4}$ & $\mathbf{4 4}$ & $\underline{\mathbf{2 7} / \mathbf{1 0 1}}$ & $\underline{\mathbf{2 7}}$ \\
\hline
\end{tabular}

Table 1 summarizes the instances from the four newspaper articles both as exact numbers relative to the total and as their corresponding percentage.

If the instances of Indirect Discourse (ID) are taken as a point of departure, it is noticeable that the newspaper with the highest percentage of these $(49 \%)$ is The Guardian, while the one with the lowest percentage (23\%) is The Sun. The British newspapers have the edge over the Bulgarian ones, with $37 \%$ against $32 \%$, respectively, when compared with each other, while the average for both the British and the Bulgarian newspapers stands at 36\% (36 instances out of 101), which is the highest percentage figure in comparison to all the other modes. ID is also the most frequently used mode by The Guardian, when looked at the distribution of instances for each individual newspaper.

The newly introduced Indirect Discourse Slipping (ID(S)) is used only two times in the two Bulgarian newspapers, and is not present in the two British articles, which is probably the reason why it is not considered by Fairclough, who analysed only the discourse representation by the British media. The fact that it is used by both analysed Bulgarian newspapers shows that it might be one specific Bulgarian way of discourse representation.

Direct Discourse representation (DD) is the third most common mode of representation, when all four newspapers are taken into account and for 24 Chasa taken individually, and it shares the third place together with UNSIG for The Guardian, while it is the first most common mode for The Sun and Monitor. With respect to the Bulgarian vs the British usage it takes second and third place, respectively.

Direct Discourse Slipping (DD(S)) is only characteristic of the British articles in the corpus. It is not manifested in the Bulgarian articles. $\mathrm{DD}(\mathrm{S})$ is the second most common mode used for discourse representation in the articles excerpted from The Guardian, while only $13 \%$ of all the instances in The Sun exhibit the application of this mode.

UNSIG is the second most commonly used mode ( $27 \%$ of all instances) by the four newspapers. However, the Bulgarian media (44\%) have relied on that mode almost two and a half times more than the British media (18\%), with 24 Chasa using it in more than a half of all its instances of discourse representation. 
Table 2.

Boundary Maintenance

\begin{tabular}{|c|c|c|c|c|c|c|c|c|c|c|c|c|c|c|}
\hline & \multicolumn{2}{|c|}{ The Guardian } & \multicolumn{2}{|c|}{ The Sun } & \multicolumn{2}{|c|}{ BR Newspapers } & \multicolumn{2}{|c|}{ Monitor } & \multicolumn{2}{|c|}{24 Chasa } & \multicolumn{2}{|c|}{$\begin{array}{l}\text { BG } \\
\text { Newspapers }\end{array}$} & \multicolumn{2}{|c|}{$\begin{array}{l}\text { BR and BG } \\
\text { Newspapers }\end{array}$} \\
\hline & No. & $\%$ & No. & $\%$ & No. & $\%$ & No. & $\%$ & No. & $\%$ & No. & $\%$ & No. & $\%$ \\
\hline 1. - & $7 / 26$ & 27 & $3 / 26$ & 12 & $10 / 52$ & 19 & $2 / 9$ & 22 & $2 / 23$ & 9 & $4 / 32$ & 13 & $14 / 84$ & 17 \\
\hline 2.DISS & $1 / 26$ & 4 & $3 / 26$ & 12 & $4 / 52$ & 8 & $1 / 9$ & 11 & $1 / 23$ & 4 & $2 / 32$ & 6 & $6 / 84$ & $z$ \\
\hline 3.INC/DISS & $8 / 26$ & 31 & $10 / 26$ & 38 & $18 / 52$ & 35 & $5 / 9$ & 56 & $19 / 23$ & 83 & $24 / 32$ & 75 & $42 / 84$ & $\underline{50}$ \\
\hline 4.INC & $10 / 26$ & 38 & $10 / 26$ & 38 & $20 / 52$ & 38 & $1 / 9$ & 11 & $1 / 23$ & 4 & $2 / 32$ & 6 & $22 / 84$ & 26 \\
\hline
\end{tabular}

Concerning the commitment of the media to represent the secondary discourse as faithfully as possible, now, we turn to Table 2 , which summarizes the quantitative findings of the research with respect to the distribution of the instances of incorporation and dissemination between the individual newspapers, as well as the British media discourse vs the Bulgarian media discourse. A look at the first row of the table, which shows the number and the percentage of instances, where the secondary discourse has been represented faithfully (no incorporation, nor dissemination), reveals that less than two fifths (17\%) of all the instances do not show any alteration of the secondary discourse or preservation of its authority in the primary discourse. It is also evident that the averages for the British $(19 \%)$ and the Bulgarian discourse (13\%) have a difference of $6 \%$, with The Guardian (27\%) and Monitor (22\%) being much more committed to the faithful representation of the quoted sources than The Sun (12\%) and 24 Chasa (9\%).

If we look at the deviations from the commitment to faithful representation of the secondary discourse, we will notice that the instances showing only dissemination are $7 \%$ on average for the four newspapers, with The Sun having the highest percentage (12\%), The Guardian (4\%) and 24 Chasa (4\%) - the lowest, while Monitor (11\%) is right between them. The average for the British newspapers is $8 \%$, and for the Bulgarian newspapers $6 \%$. However, when the percentage of the instances which show only dissemination is added to the percentage of the instances showcasing both incorporation and dissemination, the percentage for all the four newspapers stands at $57 \%$. The combined number for the British media discourse is slightly lower at $43 \%$, while for the Bulgarian media discourse that number stands at $81 \%$. It shows that the Bulgarian media tends to preserve and transmit the authority of the quoted sources more than twice as much as the British media.

With respect to the instances of alteration of secondary discourse, $26 \%$ of the instances in all four newspapers exhibit only incorporation and additionally $50 \%$ include both incorporation and dissemination. It means the secondary discourse has been altered in some way in $76 \%$ of the instances in the four newspapers. These figures stand at $73 \%$ for the British newspapers and $81 \%$ for 
the Bulgarian ones, which shows that the Bulgarian media are more inclined to alter the secondary discourse while representing it to its readership. Here we can draw a diachronic comparison with the findings of Fairclough, which are based on articles published in the UK in 1985 (some 33 years before the articles used for the present research). Fairclough found out that $71 \%$ of the instances from the five newspaper articles that he analysed show incorporation, which is comparable to the $73 \%$ that were found out in the present research. Unfortunately, it was not possible to find a previous study based on articles from the Bulgarian media discourse to compare the findings of this research to, so only a diachronic comparison of the findings for the British media discourse was feasible. As for the individual newspapers, when the combined figures for incorporation and incorporation plus dissemination are taken into account, it becomes evident that The Sun (76\%) is more inclined to alter the secondary discourse than The Guardian (69\%). For the Bulgarian media, 24 Chasa with $87 \%$ of instances which involve incorporation and incorporation plus dissemination show much more inclination towards alteration of the secondary discourse than Monitor (67\%). Taking into account the fact that The Guardian and Monitor are considered more serious press than The Sun and 24 Chasa, the observation that the latter have altered the secondary discourse to a greater degree comes as no surprise, but it is also evident that even the more serious press have not refrained from secondary discourse alteration.

Table 3.

Interaction between Indirect Discourse and Boundary Maintenance

\begin{tabular}{|c|c|c|c|c|c|c|c|c|c|c|c|c|c|c|}
\hline \multicolumn{15}{|c|}{ INDIRECT DISCOURSE (ID) } \\
\hline & \multicolumn{2}{|c|}{$\begin{array}{l}\text { The } \\
\text { Guardian }\end{array}$} & \multicolumn{2}{|c|}{ The Sun } & \multicolumn{2}{|c|}{ BR Newspapers } & \multicolumn{2}{|c|}{ Monitor } & \multicolumn{2}{|c|}{24 Chasa } & \multicolumn{2}{|c|}{$\begin{array}{l}\text { BG } \\
\text { Newspapers }\end{array}$} & \multicolumn{2}{|c|}{$\begin{array}{l}\mathrm{BR} \text { and } \mathrm{BG} \\
\text { Newspapers }\end{array}$} \\
\hline & No. & $\%$ & No. & $\%$ & No. & $\%$ & No. & $\%$ & No. & $\%$ & No. & $\%$ & No. & $\%$ \\
\hline 1. & $5 / 18$ & 28 & $0 / 7$ & 0 & $5 / 25$ & 20 & $2 / 3$ & 67 & $2 / 8$ & 25 & $4 / 11$ & 36 & $9 / 36$ & $\underline{25}$ \\
\hline 2.DISS & $1 / 18$ & 5 & $0 / 7$ & 0 & $1 / 25$ & 4 & $0 / 3$ & 0 & $1 / 8$ & 13 & $1 / 11$ & 9 & $2 / 36$ & $\underline{6}$ \\
\hline 3.INC/DISS & $3 / 18$ & 17 & $1 / 7$ & 14 & $4 / 25$ & 16 & $0 / 3$ & 0 & $4 / 8$ & 50 & $4 / 11$ & 36 & $8 / 36$ & 22 \\
\hline 4.INC & $9 / 18$ & 50 & $6 / 7$ & 86 & $15 / 25$ & 60 & $1 / 3$ & 33 & $1 / 8$ & 13 & $2 / 11$ & 18 & $17 / 36$ & 47 \\
\hline
\end{tabular}

It is interesting to see the interaction between the parameters mode of representation and boundary maintenance, which is shown in tabular fashion above. With respect to Indirect Discourse, $20 \%$ of the instances from the British newspapers and 36\% from the Bulgarian ones, which equals to $25 \%$ in the combined figure, have represented the secondary discourse without any alteration or preservation of its authority. As for the individual newspapers The Guardian (28\%) and Monitor (67\%) have a much larger percentage of instances without any alteration, than The Sun (0\%) and 24 Chasa (25\%), respectively. The Bulgarian media have shown less deviation from the commitment to faithful representation of the secondary discourse through the mode Indirect 
Discourse. Here is an example excerpted from Monitor, which shows ID with no incorporation or dissemination, together with the paragraph from the press conference, which has been reported:

[1] Първанов посочи, че пет пьти от „Булмаркет“ са подавани молби до прокуратурата за изземване и съхраняване на елементи от стрелка номер 5, железния път и траверсите, но е получаван писмен отказ (Parvanov pointed out that five times Bulmarket had submitted requests to the prosecutor's office for seizure and storage of elements from arrow No 5, the railway and the sleepers, but a written refusal had been received). ( $\left.\mathrm{M}^{4} / 24.01 .20\right)$; [2] Булмаркет Рейл Карго подаде пет писмени молби тогава до прокуратурата да се изземат и съхранят елементи от стрелка номер пет от железния път и от траверсите. На тези пет молби има писмен отказ да се извърши това действие. (Then Bulmarket Rail Cargo submitted five written requests to the prosecutor's office for elements of arrow No five from the railway and from the sleepers to be expropriated and stored. These five requests were turned down in writing.) (PC).

Example [1], which reports [2] has a neutral word order, with an introductory clause, followed by a reporting clause introduced with the conjunction ye (that). The verbs in the reporting clause are in the expected special reporting tenses, which show that the person who reports the statement has not witnessed it. The journalist who reports Parvanov's words distances himself from the reported statements and thus does not preserve the authority of the secondary discourse. What is more, there are not any vocabulary changes in the reported sentence. However, the single reported sentence represents two sentences in the secondary discourse and thus this proves Fairclough's observation (1995, p. 56) that ID does not always express a commitment to representation of the full ideational meaning of the secondary discourse.

Let us now turn to the interaction between Indirect Discourse and dissemination. The combination of Indirect Discourse and dissemination without incorporation is quite rare $-6 \%$ for the four newspapers altogether, $4 \%$ for the British media discourse and $9 \%$ for the Bulgarian media discourse. There are only two instances showing that combination in The Guardian and 24 Chasa. Here is the example from 24 Chasa, together with the source sentences from the press conference:

4. The abbreviations used in this analysis are as follows: "M" stands for Monitor; "G" - The Guardian; "PC" stands for the press conference of Bulmarket in the town of Ruse; "24 Ch" stands for 24 Chasa; "I" stands for the transcript of the hearing of Grenfell Fire Inquiry held on $4^{\text {th }}$ June 2018; "DBL" stands for Dr Barbara Lane Report published on the site of the inquiry on $4^{\text {th }}$ June 2018; "c" - caption; "S" - The Sun"; /h/" stands for headline; 
[3] Лошото състояние на жп-мрежата е причинило инцидента в Хитрино, твърдят от БУЛМАРКЕТ (The bad condition of the railway network caused the incident in Hitrino, BULMARKET claims) $/ \mathrm{h} /$ (24Ch/24.01.20); [4] Според заключенията от последните експертизи по делотов Шуменския окръженсъд, ааа... състоянието на железопътната инфраструктура е изключително лошо... Убедени сме, че основната причина е състоянието на железопьтната инфраструктура и че трябва да се вземат спешни мерки за предотвратяване на бъдещи инциденти (According to the conclusions of the latest expert reports on the case in the Shumen District Court, er... the condition of the railway infrastructure is extremely bad... We are convinced that the main reason is the condition of the railway infrastructure and that urgent measures must be taken to prevent future incidents). (PC).

First of all, here the word order deviates from the neutral word order of example [1], where the primary discourse introduces the secondary discourse. In [3] it is the secondary discourse which comes first in the sentence and is put in focus and thus its authority is allowed to dominate, with the primary discourse, which is still present, coming almost as an afterthought and whose authority is consequently weakened. The tense of the verb in the reporting clause is the expected special reporting tense, showing that the journalist reports something heard but not witnessed, which weakens the preserved authority of the secondary discourse to a certain extent. Similarly to the previous example, the reported sentence [3] combines information from two different sentences from the press conference, e.g. [4], which are a few sentences apart from each other giving further evidence for the observation of Fairclough (1995, p. 56) mentioned earlier that ID does not always express a commitment to representation of the full ideational meaning of the secondary discourse. Example [3] shows the contextualisation of the secondary discourse with the help of the reporting verb, which will be discussed in the section concerning the parameter setting.

Looking at the interaction between Indirect Discourse and incorporation plus dissemination, we can see that $22 \%$ of all the instances of Indirect Discourse in the four newspapers exhibit incorporation plus dissemination. In relative terms, the Bulgarian newspapers have a much higher incidence $(36 \%)$ than the British media (16\%), but in absolute terms they have the same number of instances. The Guardian has three instances, The Sun has one and 24 Chasa has four. Let us look at example [5] from The Guardian, which is based on examples 6-9 from the hearing of the inquiry into the fire and from Dr Barbara Lane's report:

[5] Serious fire safety breaches at Grenfell Tower included over 100 noncompliant fire doors, a fire fighting lift that didn't work and a "stay put" policy that totally failed, the inquiry into the disaster has been told. (G/ 04.06.2018); [6] This was a programme of works which were intended to replace 106 flat entrance doors with fire doors which complied with 
relevant fire safe standards. (I); [7] I have found that the flat entrance fire doors which were installed, were not in compliant with the relevant test evidence provided. (DBL); [8] Evidence is beginning to emerge that the first crew at the scene discovered that the firefighter switch for the lifts, which would give the London Fire Brigade sole control over the lifts, was not operational (I). [9] I consider the Stay Put strategy required from the Building condition, to have effectively failed by 01:26 (DBL).

Similarly to example [3], example [5] shows the same deviation from the word order of a neutral Indirect Discourse sentence but here the tenses in the fronted reporting clause have not been back shifted and thus more of the authority of the secondary discourse is preserved in comparison with [3], which shows the adoption of the expected reporting tenses in Bulgarian. Example [5] reports four sentences from two original sources and is the strongest proof so far of Fairclough's observation that ID does not always express the full ideational meaning of secondary discourse. Example [5] also shows incorporation, where the substitution of the exact number 106 with over 100, the firefighter switch for the lifts with fire fighting lift and the adverb effectively with totally are vocabulary changes that have been made to the original lines.

As is seen from Table 3, the combination of Indirect Discourse and incorporation covers almost half of all the instances of Indirect Discourse in the four newspapers. It is especially prominent in The Sun, where all the instances of ID include either incorporation (86\%) or incorporation and dissemination (14\%). The following example, which shows ID with incorporation is excerpted from The Sun:

[10] The public inquiry into the disaster heard today there were a catalogue of safety failings in the West London tower block /c/ (S/05.06.2018); [11] However, the number of non-compliances signify a culture of noncompliance at Grenfell Tower (DBL).

Example [10] is a caption under a picture showing the whole tower alit with thick black smoke coming out of it. This instance shows the substitution of a culture from Dr Lane's report with a catalogue in The Sun's article and the substitution of non-compliances with safety failings. A look at the dictionary definitions of culture and catalogue is revealing about the motivation for this substitution. Longman Dictionary of Contemporary English defines culture as "the attitudes and beliefs about something that are shared by a particular group of people or in a particular organization" (LDCE 2003, p. 382) and a catalogue of as "a series of mistakes, crimes etc that happen one after the other and never seem to stop". As seen, despite denoting similar ideas, the connotative layers of culture and catalogue definitely differ, with catalogue pointing into the direction of crime and wrongdoing. 
Now, let us focus on the interaction between Direct Discourse and Boundary Maintenance, which is represented in Table 4.

Table 4.

Interaction between Direct Discourse and Boundary Maintenance

\begin{tabular}{|c|c|c|c|c|c|c|c|c|c|c|c|c|c|c|}
\hline \multicolumn{15}{|c|}{ DIRECT DISCOURSE (DD) } \\
\hline & \multicolumn{2}{|c|}{ The Guardian } & \multicolumn{2}{|c|}{ The Sun } & \multicolumn{2}{|c|}{ BR Newspapers } & \multicolumn{2}{|c|}{ Monitor } & \multicolumn{2}{|c|}{24 Chasa } & \multicolumn{2}{|c|}{$\begin{array}{l}\text { BG } \\
\text { Newspapers }\end{array}$} & \multicolumn{2}{|c|}{$\begin{array}{l}\text { BR and BG } \\
\text { Newspapers }\end{array}$} \\
\hline & No. & $\%$ & No. & $\%$ & No. & $\%$ & No. & $\%$ & No. & $\%$ & No. & $\%$ & No. & $\%$ \\
\hline 1. & $2 / 4$ & 50 & $3 / 11$ & 27 & $5 / 15$ & 33 & $0 / 4$ & 0 & $0 / 2$ & 0 & $0 / 6$ & 0 & $5 / 21$ & 24 \\
\hline 2.DISS & $0 / 4$ & 0 & $3 / 11$ & 27 & $3 / 15$ & 20 & $1 / 4$ & 25 & $0 / 2$ & 0 & $1 / 6$ & 17 & $4 / 21$ & 19 \\
\hline 3.INC/DISS & $1 / 4$ & 25 & $1 / 11$ & 9 & $2 / 15$ & 13 & $3 / 4$ & 75 & $2 / 2$ & 100 & $5 / 6$ & 83 & $7 / 21$ & 33 \\
\hline 4.INC & $1 / 4$ & 25 & $4 / 11$ & 36 & $5 / 15$ & 33 & $0 / 4$ & 0 & $0 / 2$ & 0 & $0 / 6$ & 0 & $5 / 21$ & 24 \\
\hline
\end{tabular}

The number of instances in DD, which do not exhibit any form of incorporation or dissemination equals $24 \%$ ( 5 out of 21 instances) for the combined instances from the British and the Bulgarian media discourse, while for the Bulgarian newspapers it is $0 \%$ ( 0 out of 6 ) and for the British ones it is $33 \%$ (5 out of 15), which shows that the British newspapers show a higher commitment to the faithful representation of the secondary discourse without any alteration or preservation of its authority when Direct Discourse is concerned, which is in stark contrast with the situation concerning Indirect Discourse, which showed the reversed trend. When the individual newspapers are looked at, The Guardian (50\%) stands out as the one with the highest commitment, while 25 Chasa (0\%) and Monitor (0\%) show the lowest commitment, with The Sun (27\%) coming in between, which presents us with some evidence that possibly even the representatives of the British gutter press have a higher level of objective representation of secondary discourse than the Bulgarian newspapers, which are considered a more serious press, like Monitor.

[12] Referring to the "stay put" advice, he said: "It may be that the formal maintenance of that advice until 2.47 am made all the difference between life and death" (G/04.06.2018); [13] On the other hand, it may be that the formal maintenance of that advice until 2.47 am made all the difference between life and death (I).

Example [12], extracted from The Guardian, shows DD without any alteration or dissemination. It starts with introductory primary discourse and clearly marks where the secondary discourse begins and ends. Between the quotation marks the secondary discourse from [13] is represented verbatim without any changes. This instance exemplifies what one expects when they look at a quoted utterance, but, unfortunately, as is seen from the research results, such instances are more of an exception that the norm. 
A combination, which still keeps the secondary discourse unaltered is DD, which shows only dissemination. Table 4 reveals that further $19 \%$ from the instances in the four newspapers do not show alteration of the secondary discourse but display preservation of its authority and the situation between the British newspapers (20\%) and the Bulgarian newspapers $(17 \%)$ is not that different.

[14] „Независимо с каква скорост се е движела влаковата композиция, тя е можела да дерайлира. Убедени сме, че основната причина е състоянието на железопьтната инфраструктура и че трябва да се вземат спешни мерки за предотвратяване на бъдещи инциденти“, допълни той. ("No matter how fast the train had been moving, it could have derailed. We are convinced that the main reason is the condition of the railway infrastructure and that urgent measures must be taken to prevent future accidents," he added.) (M/24.01.20); [15]... независимо с каква скорост се движи влаковата композиция, тя е могла да дерайлира. Убедени сме, че основната причина е състоянието на железопътната инфраструктура и че трябва да се вземат спешни мерки за предотвратяване на бъдещи инциденти. (no matter how fast the train had been moving, it could have derailed. We are convinced that the main reason is the state of the railway infrastructure and that urgent measures must be taken to prevent future accidents.) (PC).

In [14], taken from Monitor, which quotes [15], the placement of the reporting verb after the reported string undermines the authority of the primary discourse and thus the secondary discourse wields its authority.

If we look at the statistical data (Table 4), which shows the percentage of instances that show alteration of the secondary discourse, we will see that $57 \%$ of all instances in the four newspapers show incorporation within DD either alone or in conjunction with dissemination, which contrasts sharply with what Leech and Short (1981, p. 257) suggest concerning DD, namely that the person who reports in direct discourse claims to report faithfully both what is said and the exact words, which are used. These differences arise from the fact that Leech and Short discuss Direct and Indirect Discourse in the light of fictional literary works, while the findings of the present research concern media usage. Even so, when quotations are concerned, what Leech and Short suggest is the expected commitment and it is unfortunate that both the British and the Bulgarian media have not completely committed to the faithful representation of the exact form of the quoted utterances. It is fair to notice, though, that the Bulgarian media with their $83 \%$ of deviation have shown twice less commitment than the British media, which have $46 \%$ of instances with deviation. Here is an example from The Sun, which shows the nature and the extent of deviation of 
the published quotation in comparison with the original line from the transcript of the inquiry:

[16] Mr Millet explained: "Polyethylene is combustible, which melts and drips when exposed to heat" ( $\mathrm{S} / 05.06 .18)$; [17] Now, polyethylene is a combustible synthetic thermoplastic polymer which melts and drips upon exposure to heat and which can also flow whilst burning. (I).

The omission of synthetic thermoplastic polymer and the substitution of the prepositional phrase upon exposure to heat from the original line [17] with when exposed to heat in example [16] shows some of the more significant alterations of the quoted material, found in the British newspapers, which involve small changes, such as omissions of words or articles and substitutions of words or phrases, which can also be characteristic of some of the instances of incorporation in the Bulgarian discourse. However, some of the examples from the Bulgarian media show more radical changes, like the ones in example [18], excerpted from 24 Chasa, which shows DD with both incorporation and dissemination:

[18] „Търсеха се, изземаха се и се подлагаха на експертизи само и единствено предмети, данни и факти, които са в подкрепа на обвинителната теза. ... Дали причината за тенденциозното разследване е оказания върху разследващия екип от НСлС натиск от зам.-главния прокурор или причината е някъде другаде, е въпрос, който също търси своя отговор“, допълни Първанов. (“Only objects, data and facts that support the indictment were searched for, taken as samples and subjected to expertise. ... Whether the reason for the biased investigation is the pressure exerted on the investigation team by the Deputy Prosecutor General or the reason is somewhere else, is a question that is also looking for its answer," Parvanov added). (24 Ch/24.01.20).

What is interesting is the fact that none of the British newspapers have more than two sentences in a single quotation, while 24 Chasa has two instances, where either 5 or 6 sentences are quoted together. Example [18] is the fivesentence quotation from 24 Chasa but to save space, only the first and the last sentence from the quotation are given. Were all these sentences to have been considered separately, the number of the instances of incorporation within DD in the Bulgarian discourse representation would have soared. Similarly to some of the previous examples, which show dissemination, here the placement of the primary discourse clause at the end of the string allows the secondary discourse to become more authoritative.

[19] В българското право, а и не само в българското право е задължително провежданетона обективно и всестранно разследване, което означава, че трябва да се събират факти и доказателства, 
както в подкрепа на обвинителната теза, така и въобще в подкрепа на каквато и да е друга теза. ...Булмаркет Рейл Карго подаде пет писмени молби тогава до прокуратурата да се изземат и съхранят елементи от стрелка номер пет от железния път и от траверсите. На тези пет молби има писмен отказ да се извърши това действие. Тези вещи не са изземани, не се съхраняват никъде... естествено не могат да се изследват. Дали причината за тенденциозното разследване е оказания натиск върху разследващия екип от Националната следствена служба, от заместник-главния прокурор или е някаква друга причината, ние не знаем, но според мен този въпрос много активно очаква своя отговор. (Under the Bulgarian legislation, and not only under the Bulgarian legislation, it is mandatory to conduct an objective and thorough investigation, which means that facts and evidence must be collected, both in support of the accusatory thesis and in general in support of any other thesis. ... At the/ that time Bulmarket Rail Cargo submitted five written requests to the prosecutor's office for collection and storage of samples from arrow No five, from the railway, and from the sleepers. These five requests were refused in writing. These items are not collected; they are not stored anywhere... of course they cannot be examined. Whether the reason for the biased investigation is the pressure exerted on the investigation team by the National Investigation Service, the Deputy Prosecutor General or there is some other reason, we do not know, but in my opinion this question is very actively awaiting its answer.) (PC).

Now, let us compare example [18] with the original lines [19] from the press conference to see the nature of the alterations which the secondary discourse has undergone. First of all, it is clear that the first sentence from [18] in its entirety has not been pronounced at the press conference but the gist of it by implication can be found scattered around different sentences. The first sentence in [18] is in the passive voice, which in Bulgarian can be formed in two different ways. The first way, which is similar to the way the passive voice is formed in English relies on the use of the auxiliary verb $c b m$ (be) which changes according to the desired tense and the past participle of the finite verb, which denotes the meaning. The second way, which is the one chosen for the first sentence in example [18], relies on the use of the reflexive particle ce added to the full verb. The word order in the sentence is not the expected word order, which should start with the noun group serving as the grammatical subject of the sentence and then followed by the verb group. Here, the sentence starts with a verb group and thus the actions denoted by the verb group are emphasized. The verb group includes three full verbs rather than one, and the noun group consists of three subjects. This is a concise sentence, which contains a lot of information in a very small form factor, in most cases referring implicitly to at least three sentences 
from the secondary discourse. The motivation for such a sentence is obvious: it both saves space and presents the ideas from the secondary discourse in a clear way. However, it shows a drastic change of the form of the secondary discourse, while typographically, it is demarcated as representing the secondary discourse without any alteration, and while incorporation within ID can be thought of as being more expected, incorporation within DD is seen as a form of insincerity. The last sentence from [18] is an example of a more moderate alteration in the Bulgarian discourse.

\section{Table 5.}

Interaction between Direct Discourse and Boundary Maintenance

\begin{tabular}{|c|c|c|c|c|c|c|c|c|c|c|c|c|c|c|}
\hline \multicolumn{15}{|c|}{ UNSIGNALLED (UNSIG) } \\
\hline & \multicolumn{2}{|c|}{ The Guardian } & \multicolumn{2}{|c|}{ The Sun } & \multicolumn{2}{|c|}{\begin{tabular}{|l|} 
BR \\
Newspapers
\end{tabular}} & \multicolumn{2}{|c|}{ Monitor } & \multicolumn{2}{|c|}{24 Chasa } & \multicolumn{2}{|c|}{\begin{tabular}{|l} 
BG \\
Newspapers
\end{tabular}} & \multicolumn{2}{|c|}{$\begin{array}{l}\text { BR and BG } \\
\text { Newspapers }\end{array}$} \\
\hline & No. & $\%$ & No. & $\%$ & No. & $\%$ & No. & $\%$ & No. & $\%$ & No. & $\%$ & No. & $\%$ \\
\hline 1. - & $0 / 4$ & 0 & $0 / 8$ & 0 & $0 / 12$ & 0 & $0 / 2$ & 0 & $0 / 13$ & 0 & $0 / 15$ & 0 & $0 / 27$ & $\underline{0}$ \\
\hline 2.DISS & $0 / 4$ & 0 & $0 / 8$ & 0 & $0 / \mathbf{1 2}$ & 0 & $0 / 2$ & 0 & $0 / 13$ & 0 & $0 / 15$ & 0 & $0 / 27$ & $\underline{0}$ \\
\hline 3.INC/DISS & $4 / 4$ & 50 & $8 / 8$ & 100 & $12 / 12$ & 100 & $2 / 2$ & 100 & $13 / 13$ & 100 & $15 / 15$ & 100 & $27 / 27$ & 100 \\
\hline 4.INC & $0 / 4$ & 50 & $0 / 8$ & 0 & $0 / 12$ & 0 & $0 / 2$ & 0 & $0 / 13$ & 0 & $0 / 15$ & 0 & $0 / 27$ & $\underline{\underline{\theta}}$ \\
\hline
\end{tabular}

As far as the interaction between UNSIG and Boundary Maintenance is concerned all instances of UNSIG from the four newspapers involve both incorporation and dissemination. Let us see four examples from each of the newspapers. The first two examples are from the British media discourse.

[20] One survivors' group has claimed in evidence to the inquiry that many more people would have survived if the advice had been revoked earlier. (G/04.06.2018); [21] Now, the submissions of the G3 group of bereaved, survivors and residents assert at paragraph 68 that it is "beyond argument" that many more would have survived than did survive if the stay-put policy had been abandoned at $1.26 \mathrm{am}$, or at any rate long before 252.47 am. (I); [22] So far 135 written statements have been taken from survivors and residents, including 60 people who escaped from the tower on the night. (S/05.06.18); [23] As matters currently stand, the inquiry has received a total of 135 written witness statements from bereaved, survivors and residents; 60 from survivors who escaped the tower and 75 from other witnesses, including bereaved, residents who were not present and observers. (I).

If example [20] from The Guardian is read without comparing it with lines [21] from the transcript of the hearing, it is easy for anyone to be persuaded into thinking that this is primary discourse reporting the opening statement of lawyers representing some of the survivors during the hearing. It turns out that this is Mr Millet - the only speaker (apart from the chairman Sir Martin 
Moore-Bick) during the hearing, who first quotes written submissions from the G3 group of bereaved, survivors and residents and then reacts to their assertion, which is not presented here. In a very similar fashion example [22] from The Sun presents the words of Mr Millet [23] reporting some statistical data as primary discourse. As far as incorporation is concerned, the verb assert from [21] has been substituted with claim in [20], and the quoted phrase beyond argument from [21] has been omitted in [20]. The verb receive from [23] has been substituted with take in [22] and the active construction in [23] has been substituted with a passive construction in [22]. By the use of UNSIG, some facts from the hearing, concerning who said what, have not been reported accurately, but apart from that the changes are more or less stylistic.

[24] Според нас основната причина е състоянието на железопьтната инфраструктура и спешно трябва да се вземат мерки за да се предотвратят бъдещи инциденти (In our opinion, the main reason is the condition of the railway infrastructure and urgent measures must be taken to prevent future incidents) (24 Ch/24.01.20); [25] Убедени сме, че основната причина е състоянието на железопьтната инфраструктура и че трябва да се вземат спешни мерки за предотвратяване на бъдещи инциденти (We are convinced that the main reason is the state of the railway infrastructure and that urgent measures must be taken to prevent future incidents) (PC).

Example [24] from 24 Chasa starts with the phrase cnoped нac (in our opinion), which can mislead the casual reader into thinking that this is the media representatives who express their opinion. This definitely is dissemination of a higher order than the one found in examples [20] and [22] taken from the British media discourse. Even though the framework does not provide a scale for measurement of the degree of dissemination, it is clear that this example has a higher impact factor than the examples from the British media.

[26] Машинистите нямат решаваща вина за инцидента в Хитрино, ние твърдо стоим зад тях. (The train drivers are not to blame for the accident in Hitrino, we stand firmly behind them.) (M/24.01.20); [27] Какви ще бъдат действията на машинистите и техните защитници към настоящия момент не ни е известно, но предполагаме, че те ще обжалват присьдата... ааа... но какви... каквото и решение да вземат искам да знаете, че ние твърдо стоим зад тях. ... Това са аргументите ни да считаме, че машинистите не са виновни в причинения инцидент (What the actions of the train drivers and their defenders will be at the moment we do not know, but we assume that they will appeal the verdict... aaa... but whatever ... whatever decision they make I want you to know that we stand firmly behind them. ... These 
are our arguments to believe that the drivers are not to blame for the accident). (PC).

Example [26] from Monitor similarly to example [24] from 24 Chasa is ambiguously worded because the deictic ние (we) may refer either to the representative of Bulmarket or the journalist and editors working for Monitor. Of course, such examples are part of a wider context and readers will probably work out that this is the opinion of Bulmarket and not the opinion of the journalist writing the article and the editors of the article who have approved of its publication. Even so, the fact that these examples have been typographically demarcated as primary discourse signifies that the voice of the journalist endorses the statements made by Bulmarket and thus the secondary discourse is ascribed massive legitimacy.

\section{Table 6.}

Stylisticity and Situationality

\begin{tabular}{|c|c|c|c|c|c|c|c|c|c|c|c|c|c|c|}
\hline \multicolumn{15}{|c|}{ STYLISTICITY AND SITUATIONALITY } \\
\hline & \multicolumn{2}{|c|}{ The Guardian } & \multicolumn{2}{|c|}{ The Sun } & \multicolumn{2}{|c|}{\begin{tabular}{|l|} 
BR \\
Newspapers \\
\end{tabular}} & \multicolumn{2}{|c|}{ Monitor } & \multicolumn{2}{|c|}{24 Chasa } & \multicolumn{2}{|c|}{$\begin{array}{l}\text { BG } \\
\text { Newspapers }\end{array}$} & \multicolumn{2}{|c|}{$\begin{array}{l}\mathrm{BR} \text { and } \mathrm{BG} \\
\text { Newspapers }\end{array}$} \\
\hline & No. & $\%$ & No. & $\%$ & No. & $\%$ & No. & $\%$ & No. & $\%$ & No. & $\%$ & No. & $\%$ \\
\hline STYLE & $2 / 26$ & 8 & $0 / 26$ & 0 & $2 / 52$ & 4 & $0 / 9$ & 0 & $0 / 23$ & 0 & $0 / 32$ & 0 & $2 / 84$ & 2 \\
\hline SIT & $11 / 26$ & 42 & $5 / 26$ & 19 & $16 / 52$ & 31 & $1 / 9$ & 11 & $2 / 23$ & 9 & $3 / 32$ & 9 & $19 / 84$ & 23 \\
\hline
\end{tabular}

As seen from Table 6 stylistisity is very low. From the 84 instances of discourse representation only 2 instances exhibit the representation of stylistic meanings of the secondary discourse. Situationality is a bit higher and 19 out of the 84 instances in the four newspapers (23\%) represent the context of situation. Most of the instances of situationality represent the tenor of discourse, while some of the instances represent the field of discourse. The British media (31\%) have represented the context of situation much more than the Bulgarian media $(9 \%)$. Stylistisity and situationality are used as setting devices and will be discussed qualitatively in the section concerning the parameter setting.

\section{Table 7.}

\section{Setting}

\begin{tabular}{|c|c|c|c|c|c|c|c|c|c|c|c|c|c|c|}
\hline \multicolumn{15}{|c|}{ SETTING } \\
\hline & \multicolumn{2}{|c|}{ The Guardian } & \multicolumn{2}{|c|}{ The Sun } & \multicolumn{2}{|c|}{\begin{tabular}{|l} 
BR \\
Newspapers
\end{tabular}} & \multicolumn{2}{|c|}{ Monitor } & \multicolumn{2}{|c|}{24 Chasa } & \multicolumn{2}{|c|}{$\begin{array}{l}\text { BG } \\
\text { Newspapers }\end{array}$} & \multicolumn{2}{|c|}{$\begin{array}{l}\text { BR and BG } \\
\text { Newspapers }\end{array}$} \\
\hline & No. & $\%$ & No. & $\%$ & No. & $\%$ & No. & $\%$ & No. & $\%$ & No. & $\%$ & No. & $\%$ \\
\hline $\mathrm{F}$ & $1 / 26$ & 0.26 & $3 / 26$ & 12 & $4 / 52$ & 8 & $2 / 9$ & 22 & $2 / 23$ & 9 & $4 / 32$ & 13 & $8 / 84$ & 10 \\
\hline IF & $5 / 26$ & 19 & $5 / 26$ & 19 & $10 / 52$ & 19 & $4 / 9$ & 44 & $9 / 23$ & 39 & $13 / 32$ & 41 & $23 / 84$ & 27 \\
\hline $\begin{array}{l}\text { TOTAL } \\
\text { SETTING }\end{array}$ & $15 / 26$ & 58 & $11 / 26$ & 42 & $26 / 52$ & 50 & $5 / 9$ & 56 & $10 / 23$ & 43 & $15 / 32$ & 47 & $41 / 84$ & 49 \\
\hline
\end{tabular}


Table 7 shows that apart from stylistisity and situationality, whose data is represented on Table 6, the British and the Bulgarian media have relied on two more types of setting devices for the contextualization of the secondary discourse with the intention of controlling its interpretation by the reader, which are formulation (F) and the representation of the illocutionary force of the secondary discourse through the reporting verb (IF). As far as the combined figure of the four newspapers is concerned, $10 \%$ of the instances ( 8 out of 84) show the implementation of formulation, and the Bulgarian newspapers have a slightly larger percentage (13\%) than the British ones. Here is an instance of the representation of the context of situation from the British media discourse:

[28] Jose Torero, academic and fire safety expert, came to a damning conclusion about the building regulation system, stating that "systems that introduce obvious dangers can be incorporated by designers in a routine manner." (G/04.06.18).

Example [28] shows the representation of the tenor of discourse with the phrase academic and fire safety expert and the use of the style adjunct damning as a setting device. The already discussed example [10] reprinted for clarity below is an example of representation of the field of the secondary discourse.

[10] The public inquiry into the disaster heard today there were a catalogue of safety failings in the West London tower block /c/ (S/05.06.18).

The introductory clause of example [10], which is primary discourse, shows the context of situation with the noun phrase the public inquiry into the disaster and the deictic today, where the use of the deictic is an example of a factual error. Deictic expressions do not have a meaning of their own, but they change their meaning depending on who, in what circumstances uses them. In the context of an article, the deictic today should refer to the date on which the article is published. The date and time specified in the article in The Sun are 5 June 2018, 0:55. The hearing of the inquiry reported in the article was held on 4 June 2018. Obviously, by looking at the time of the publication, it becomes evident that the article was prepared on 4 June and published at night. Still, it should have been indicated that the inquiry heard yesterday and not today from the point of view of the time of publication of the article. It is not clear whether this was a deliberate act or an unintentional mistake, but it shows that even the primary discourse can contain some distorted information. Example [10], which is a caption under a picture, shows the use of formulation, since it repeats the first sentence in the article in The Sun.

The Bulgarian newspapers (41\%) have represented the illocutionary force of the secondary discourse more than twice as much as the British media (19\%). Since more than one setting device is implemented in some instances, the total number of the instances, which show the implementation of different setting devices, is lower than the sum of the individual numbers for the different setting devices. 
The incidence of total setting in the four articles is $49 \%$ with the British media $(50 \%)$ having a slightly higher percentage than the Bulgarian media (47\%).

24 Chasa have relied on metapropositional verbs 8 times, which include ce аргументира (adduced arguments/ argued), твърдят (maintain, assert, claim), посочи (pointed out), which is used 3 times, припомниха (brought it up, reminded), заяви (declare, announce), which is used 2 times. There is one transcript verb - допьлни (added) in their article. There are not any neutral reporting verbs and the used metapropositional verbs are all assertives. Machin and Mayr (2012, pp. 63-64) state that even the transcript verb add might be used by the press media to give the impression that a person they are promoting offers more information, when in fact they might be presenting the same point. The analysis of the reporting verbs together with the fact that $54 \%$ of all the instances of discourse representation in the article by 24 Chasa are in UNSIG (see Table 1) show that the newspaper endorses the statements of Bulmarket.

[29] От фирмата припомниха, че през тези три години, докато траеше разследването и съдебния процес, са били умерени в публичността си (The company reminded [the audience]/ brought it up that for the past three years, during the investigation and trial, they have been moderate in their publicity). (24Ch/24.01.20).

Let us assess the use of the verb припомниха (brought sth up) in example [29], by replacing it with an alternative one, like признаха (admitted). Normally, companies who are core participants in an inquiry are frowned upon when they keep a low profile, since that can be viewed as a form of avoidance of responsibility or a silent acceptance of guilt. Thus, the use of признаха (admitted) could have been used by unfriendly media to ascribe guilt to the company. But 24 Chasa have opted for припомниха (brought it up). People who bring up a subject are in control and sound authoritative.

Monitor have relied on metapropositional verbs 3 times, including nосочu (pointed out), which is used 2 times and коментира (commented). There is one transcript verb - допьлни (added) and two neutral verbs in their article. The fact that the newspaper uses a combination of neutral and metapropositional verbs corresponds to the lower percentage of instances in UNSIG $(20 \%)$ than 24 Chasa (see Table 1), and shows that the newspaper is more moderate in its representation, while still showing inclination towards presupposing positive interpretation of the statements made by Bulmarket. Example [1], which was discussed above, marks a case of implementation of the verb nосочи (pointed out) by the media, which presents the representative of Bulmarket as authoritative and legitimate. 
[30] Това коментира днес в Русе заместник-управителят на „Булмаркет“ Светослав Първанов по повод на приключилото на първа инстанция дело за железопьтната катастрофа на 10 декември 2016 г., довела до смъртта на седем души. (This was commented today in Ruse by the Deputy Manager of Bulmarket Svetoslav Parvanov on the occasion of the closed case in the first instance on the railway accident on December 10, 2016, which resulted in the death of seven people.) $(\mathrm{M} / 24.01 .20)$.

Example [30] shows an instance of the newly introduced mode ID(S), characteristic only of the Bulgarian media, which "slips" into ID from UNSIG in the previous sentence, where the statement of the representative of Bulmarket (secondary discourse) was presented under the guise of primary discourse. The confusion concerning who said what from the previous sentence might have been cleared up with that sentence, but the use of the reporting verb comment with the fact that the author has shown that they share the opinion of Parvanov further ascribe legitimacy to the statement of the company.

The Guardian have used neutral structuring verbs 14 times, and have relied on metapropositional verbs 5 times, which include claimed, insisted, stating, revealed, and warned. The ratio between the neutral and prepositional verbs is almost 3 to 1 , which shows that most of the time the newspaper has allowed the readers to derive the illocutionary force of the secondary discourse on their own. Let us look at some examples, where the illocutionary force of the secondary discourse is explicitly stated in the primary discourse. We will start with the already discussed example [20], reprinted below, and example [31], which happen to be two adjacent sentences in the article.

[20] One survivors' group has claimed in evidence to the inquiry that many more people would have survived if the advice had been revoked earlier. (G/04.06.2018); [31] But Millett insisted that was "very far from beyond argument" and that the timing of that advice and its consequences would have to be explored in evidence. (G/04.06.18).

Example [20] uses the verb phrase claim in evidence, which sounds almost like an oxymoron, since claim is defined as "to state that something is true, even though it has not been proved", while evidence is defined as "information that is given in a court of law in order to prove that someone is guilty or not guilty". According to the taxonomy of Caldas-Coulthard (1994) claim is a metapropositional expressive and Machin and Mayr (2012, p. 61) state that the use of this word invites doubt. The use of evidence, on the other hand, invites trust. The effect of this juxtaposition of the two opposing meanings, which seem to neutralize each other, is the distancing of the newspaper from the statement. The opposing statement of Mr Millett is introduced with the verb insist, which 
was already discussed as having potential to undermine the legibility of a statement and thus the newspaper distances from that statement, too.

[32] In an opening statement that lasted most of the day, Richard Millett

$\mathrm{QC}$, counsel to the inquiry, warned the companies and organisations called to give evidence not to "indulge in a merry-go-round of buck passing". (G/04.06.18).

Example [32] shows a combination of setting devices. The secondary discourse is contextualized within a long opening statement presented by a lawyer, who is also counsel to the inquiry and has the authority to issue warnings, which gives the secondary discourse massive legitimacy. Here the newspaper endorses the claim that the core participants have to accept their respective responsibilities for the disaster, which resulted is such a great loss of life.

The Sun have used neutral structuring verbs 3 times and have relied on metapropositional verbs 2 times and have implemented one transcript verb (add) 3 times, which shows that its commitment to neutrality is lower than that of The Guardian, which corresponds to its higher usage of UNSIG (see Table 1). The two metapropositional verbs used by The Sun are explained from the already discussed example [16] and concluding from example [33].

[33] The blaze climbed 50 metres up 19 floors in just 12 minutes, with Dr Barbara Lane, a fire safety engineer, concluding in a report: "The ultimate consequence was a disproportionately high loss of life." (S/05.06.18).

In both cases quotes from experts are introduced. The contextualization of the secondary discourse in [33] is achieved with different setting devices apart from the reporting verb conclude, which presupposes the interpretation that the secondary discourse is a result of sound reasoning and thus trustworthy.

\section{Conclusion}

The results from the research allow us to draw the following conclusions:

Concerning the mode of representation, the Bulgarian newspapers prefer ID over DD, while the British ones prefer DD over ID and the combined figures show that the instances showing ID are about as many as the instances showing $\mathrm{DD}$. $\mathrm{DD}(\mathrm{S})$ is only characteristic of the British newspapers, while the newly introduced ID(S) is only characteristic of the Bulgarian newspapers. There is a very high percentage of instances in UNSIG, with the Bulgarian newspapers showing a much higher usage of that mode. This leads us to the conclusion that the Bulgarian newspapers have adopted to a higher degree the position of interpreters between their readers and the reported sources, since Indirect Discourse is the mode which allows the reporter to be in the position of an interpreter between the person whose words are reported and the person to 
whom the words are being reported and at the same time it gives more control over the report to the reporter (see Leech \& Short, 1981, pp. 256, 260). The British newspapers are more committed to represent the exact form of secondary discourse (ibid., p. 257) but as is seen from the data concerning the interaction between DD and Boundary maintenance this commitment is not absolute, since incorporation could be noticed even within instances of DD.

Concerning Boundary Maintenance, as far as the combined figures for all the modes are concerned, for the most part there is a lack of commitment to the faithful representation of the secondary discourse (a very low percentage of instances, which show neither incorporation nor dissemination) and the British media have a little bit more instances without incorporation and dissemination than the Bulgarian media. The Bulgarian media show a higher percentage of incorporation. The findings for the British media concerning incorporation are comparable, diachronically, with the findings of Fairclough, with a difference of $2 \%$ ( $73 \%$ from the present research vs $71 \%$ from the research carried out by Fairclough). Both the British and the Bulgarian media transmit the authority of the quoted sources and alter the secondary discourse, but the Bulgarian media tends to preserve and transmit the authority of the quoted sources twice as much as the British media.

As far as the boundary maintenance within the different modes is concerned, the Bulgarian media have more instances without incorporation or dissemination within the instances in ID, and have a higher percentage of instances with dissemination. Within the instances in ID, the British media have more cases with incorporation. The findings of this research support the findings of the research carried out by Fairclough that ID does not always express the full ideational meaning of secondary discourse and seem to contradict the suggestion of Leech and Short (1981), concerning the commitment of ID to represent the full ideational meaning of secondary discourse, because both the present research and Fairclough's research studied media texts, which reports other texts considered an original, giving the researcher a base for comparison, while Leech and Short's research had used literary fiction texts, where the reported lines were the fictitious words of imaginary characters, which could not be compared with an original. With respect to DD, there are not any instances without incorporation or dissemination from the Bulgarian media discourse, while one third of the instances from the British media discourse are without incorporation and dissemination. The instances with incorporation within DD from the Bulgarian media discourse are almost twice as many as the instances from the British media discourse. Also, the instances with dissemination within DD in the Bulgarian media discourse are three times as many as the instances in the British media discourse, and all the instances from the Bulgarian media discourse show dissemination. With respect to UNSIG there are no differences 
between the Bulgarian and the British media discourse since all the instances show both incorporation and dissemination.

Stylisticity is very low. There are two instances in the British media and no instances in the Bulgarian media. Situationality is higher and the British media have represented the context of situation to a greater extent than the Bulgarian media. With respect to setting, apart from stylisticity and situationality the Bulgarian and the British media have used formulation and representation of the illocutionary force of the secondary discourse through the reporting verb as setting devices. The Bulgarian media have more instances of formulation and representation of the illocutionary force of secondary discourse through the reporting verbs than the British media, which reveals that the former are more inclined to exert influence on their readers than the latter.

Despite the relative depth of the study, considering the fact that it is based on a small number of articles, the possibility of widening its scope through the addition of more articles remains strong.

\section{References:}

Caldas-Coulthard, C. R. (1994). On reporting reporting: The representation of speech in factual and factional narratives. In M. Coulthard (ed.), Advances in written test analysis (pp. 295-308). London: Routledge.

Cheshmedzieva-Stoycheva, D. (2018). Framing Muslims in the Bulgarian and the British media discourse. Shumen: Konstantin Preslavsky University Press.

Fairclough, N. (1995). Critical discourse analysis: The critical study of language. London and New York: Longman.

Fowler, R. (1991). Language in the news: Discourse and ideology in the press. London, New York: Routledge.

Halliday, M. A. K. (1978). Language as social semiotic: The social interpretation of language and meaning. London: Edward Arnold.

Heritage, J. C., \& Watson, D. R. (1979). Formulations as conventional objects. In G. Psathas (Ed.), Everyday language: Studies in ethnomethodology (pp. 124-162). New York: Irvington.

Leech, G. N., \& Short, M. (1981). Style in fiction. London: Longman.

Machin, D., \& Mayr, A. (2012). How to do critical discourse analysis: A multimodal introduction. London: SAGE Publications Ltd.

McHale, B. (1978). Free indirect speech: A survey of recent accounts. Poetics and the theory of literature, 3, 249-287.

McNair, B. (2009). News and journalism in the UK. London, New York: Routledge.

Pashov, P. (1989). Prakticheska bulgarska gramatika. Sofia: Prosveta.

Quirk, R., Greenbaum, S., Leech, G. N., \& Svartvik, J. (1972). A grammar of contemporary English. London: Longman. 
Searle, J. R. (1969). Speech acts: An essay in the philosophy of language. New York: Cambridge University Press.

Searle, J. R. (1976). A classification of illocutionary acts. Language in society, 5(1, Apr.), pp. 1-23. Cambridge: Cambridge University Press.

Summers, D. (Ed.). (2003). Longman dictionary of contemporary English. Harlow: Pearson Education Limited.

van Dijk, T. A. (2000). Ideology and discourse. A multidisciplinary introduction. Barcelona: Pompeu Fabra University. Retrieved on 24 March 2021 from http://www. discourses.org/UnpublishedArticles/Ideology\%20and\%20discourse.pdf.

Volosinov, V. I. (1973). Marxism and the philosophy of language. New York: Seminar Press. 
